vol.1 No.1 ISSN:18235-2014

\title{
Impact Of Helicobacter Pylori In Hyperemesis Gravidarum Associated With Rosacea.
}

\author{
By \\ ${ }^{1}$ Emam MA , ${ }^{2}$ El-Gayyar M ${ }^{3}$ Agha S. \\ ${ }^{1}$ The Obstetrics \& Gynaecology, ${ }^{2}$ Dermatology \& Venerology, ${ }^{3}$ Clinical Pathology Departments,Faculty of \\ Medicine,Mansoura Univeristy. \\ E-mail of the corresponding author: mae335@hotmail.com
}

\begin{abstract}
Background: Helicobacter pylori (H.pylori) infection is common in Egypt. It is implicated in causation of both hyperemesis gravidarum (H.G) and rosacea (chronic skin disease). It is diagnosed by positive serum IgG antibodies.Objective: is to detect any possible relationship between infection with H.pylori and (H.G) when associated with rosacea.Design: prospective controlled study.Setting: Ob. \& Gyn., dermatology and clinical pathology departments, Mansoura Faculty of Medicine, Egypt.Subjects : 266 non obese women, singleton pregnancy, divided into three groups; group (I): H.G without rosacea $(n=108)$, group (II): H.G with rosacea $(\mathrm{n}=46)$ and group (III), 112 pregnant women without H.G or rosacea. Results: No statistically significant difference $(\mathrm{P}>0.05)$ regarding age, gravidity, gestational age and Body mass index between three groups. Regarding the positive cases, from the qualitative and the quantitative point of view, IgG antibodies (group II versus III) showed extremely significance $(\mathrm{P}=0.001)$, while group I versus II and I versus III showed significant difference $(\mathrm{P}=0.019 \& 0.021)$ respectively. Erythematous lesions of rosacea showed the most prevalent and significant skin lesion compared to papules and pustules $(\mathrm{P}=0.14$ and 0.15$)$ respectively.Conclusions and recommendations: H.pylori infection is sugegsted to be one of the important factors in the pathogenesis of (H.G). When rosacea is associated with (H.G), the obstetrician should expect that H.pylori is often the culprit responsible for the pathogenesis of both. We recommended more studies to clarify the different non teratogenic drugs which can be used for eradication of H.pylori during the period of organogenesis. Hence a specific and a causative treatment of H.G. will be elicited.
\end{abstract}

Key words: Helicobatcer pylori, hyperemesis gravidarum and rosacea.

\section{Introduction:}

Hyperemesis gravidarum (H.G) is the most severe manifestation of the spectrum of nausea and vomiting of pregnancy, may complicate from 0.3 to $2 \%$ of all pregnancies $\left[\begin{array}{ll}\mathbf{1}, \mathbf{2}, 3 & \mathbf{3}\end{array}\right]$. In extreme cases, dehydration, electrolyte imbalance, and acid base disturbances may lead to renal and hepatic injury $\left.{ }^{[}, 5\right]$. On the other hand, patients who manifest continuous weight loss and electrolyte disturbances may be at risk for decreased neonatal birth weight, growth restriction and fetal anomalies ${ }^{[6,7,8]}$ H.pylori organism is a spiral-shaped gram negative rods found on gastric mucosa particularly the antrum ${ }^{[\mathbf{9 , 1 0}]}$. It affects more than half of the population ${ }^{[11,12]}$ is common in Egypt and acquistion of infection occurs at a very young age ${ }^{13]}$. So infection with this organism may cause H.G ${ }^{[14,15,16]}$.

Rosacea is a chronic inflammatory skin disorder which usually affects young to middle aged individuals more commonly in women in the childbearing period in the flush area of the face, mainly the nose. It is characterized by, papules, pustules and telengiectases ${ }^{[17,18,19,20]}$ On the other hand, the review of literature showed controversy regarding the relationship between H.pylori and rosacea. Many reaserches supported that rosacea may be caused by this microorganism $^{[21,18,22,23,24]}$,others considered this relationship as a myth ${ }^{[25,26]}$.

The development of H.pylori-specific fluorescent serum antibody tests allows economic screening for H.pylori infection. Due to this

Aim of study:

\section{The aim of the study was to:}

detect any possible relationship between infection with H.pylori and hyperemesis gravidarum when associated with rosacea..

\section{Subjects and Methods}

Study Design:-

prospective controlled study

\section{Setting:-}

Ob. \& Gyn., dermatology and clinical pathology departments, Mansoura Faculty of Medicine.

\section{Subjects:}

During the period from May 2010 to October 2013, two hundred and sixty six 
pregnant women (singleton prgnancy), non obese were recruited in this prospective controlled study from Ob. \& Gyn. and Dermatology departments, Mansoura University Hospital. They were divided into three groups: group (I): Hyperemesis gravidarum without rosacea $(\mathrm{n}=108)$, group (II): Hyperemesis gravidarum with rosacea $(n=46)$ and group (III): The control group comprising 112 pregnant women without hyperemesis and without rosacea.

The inclusion criteria for the gravidae with hyperemesis gravidarum were occurence of pernicious vomiting (more than three times/day), ketone in urine and exclusion of other diseases that may cause vomiting such as hyperthyrodism, hyperparathyroidism, renal and liver dysfunction, cholecystitis, and appendicitis. So the diagnostic work up started with confirmation of a single viable intrauterine pregnancy, excluding trophoblastic neoplasia. Then electrolytes, liver, thyroid, renal function tests were assayed and also urinelysis and complete blood picture were done.

Rosacea patients were selected from cases of hyperemesis gravidarum associated with redness, oedema, papules and/or pustules affecting the perioral or the butterfly area after referral to the dermatology department, because rosacea should be distinguished from many skin lesions like choloasma gravidarum, butterfly rash of systemic lupus erythematosus and from seborrhoeic dermatitis ${ }^{[22.29]}$ Then the

\section{Results:}

Table (1): The clinical criteria of the studied groups. different types of lesions (erythema, papules and/or pustules) were graded separately.

The controls were recruited from the antenatal care outpatient clinic, considering that the inclusion criteria were the same like the study groups, except there was no hyperemesis gravidarum. Serum samples were obtained from all women and were kept frozen at $-20 \mathrm{oC}$ until assayed in the clinical pathology department, Mansoura Faculty of Medicine. H.pylori specific IgG antibodies were detected with a specific enzyme-linked immuno-sorbent assay (ELISA) Kit (United Biotech Inc.), according to the manufacturer's instructions ${ }^{[30]}$.

Value higher than $40 \mathrm{Eu} / \mathrm{ml}$ was considered positive, less than 30 was negative, while 30-40 was equivocal. Optical density (O.D) was read at $450 \mathrm{~nm}$ with a microplate reader and the IgG values were obtained and expressed as units $/ \mathrm{ml}$ $(\mathrm{U} / \mathrm{ml})$. Sample $\mathrm{Eu} / \mathrm{ml}=$ (O.D of test sample / O.D of calibrator X Eu/ml of calibrator).

\section{Data analysis:}

Statistical analysis was done by using SPSS (statistical package for social science. The qualitative data were presented in the form of number and percentage. Chi-square test, F test (one way ANOVA) and Student "t" test were used. The test is significant when $(\mathrm{P}<0.05$, highly significant $(\mathrm{P}<0.01)$ and extremely significant $(\mathrm{P}<0.001) \quad$ (Park, 1997).

\begin{tabular}{|l|c|c|c|c|}
\hline $\begin{array}{c}\text { Group } \\
\text { Criteria }\end{array}$ & $\begin{array}{c}\text { Group I } \\
\mathbf{n = 1 0 8}\end{array}$ & $\begin{array}{c}\text { Group II } \\
\mathbf{n = 4 6}\end{array}$ & $\begin{array}{c}\text { Group III } \\
\mathbf{n = 1 1 2}\end{array}$ & test of significance \\
\hline $\begin{array}{l}\text { - Age } \\
\text { mean + SD (years) }\end{array}$ & $25.3+2.3$ & $25.1+2.6$ & $25.1+2.8$ & $\mathrm{P}=0.8(\mathrm{NS})$ \\
\hline $\begin{array}{l}\text { - Gravidity: } \\
\text { Prim. No (\%) }\end{array}$ & $95(87.9 \%)$ & $38(82.6 \%)$ & $104(92.8 \%)$ & $8(7.2 \%)$ \\
Multi No. (\%) & $13(12.1 \%)$ & $8(17.4 \%)$ & $\mathrm{P}=0.15$ \\
\hline $\begin{array}{l}\text { - Gestational age } \\
\text { (weeks) }\end{array}$ & $8.3+1.4$ & $8.4+1.2$ & $8.3+1.2$ & $\mathrm{NS})$ \\
\hline - BMI & $25.4+1.5$ & $25.2+1.3$ & $25.2+1.3$ & $\mathrm{P}=0.72(\mathrm{NS})$ \\
\hline
\end{tabular}

- Chi-square test was used

- NS = Non significant $\mathrm{P}>0.05$

- $\mathrm{BMI}=$ body mass index $=$ weight $\mathrm{Kgm} /$ height in $\mathrm{m} 2$ 
Table (2): The levels of IgG antibodies of H.pylori in the sera of the studied groups

\begin{tabular}{|l|c|c|c|c|c|c|c|c|}
\hline \multirow{2}{*}{\begin{tabular}{|} 
Group \\
IgG
\end{tabular}} & \multicolumn{2}{|c|}{ Group I } & \multicolumn{2}{c|}{ Group II } & \multicolumn{2}{c|}{ Group III } & \multicolumn{2}{c|}{ Test of significance } \\
\cline { 2 - 10 } & No & $\%$ & No & $\%$ & No & $\%$ & Total positive & Positive \\
\hline a) Total positive & 86 & 79.6 & 44 & 95.6 & 74 & 66.1 & $\mathrm{P} 1=0.019^{*}$ & $\mathrm{P} 1=0.021^{*}$ \\
\hline - Positive $>40 \mathrm{Eu} / \mathrm{ml}$ & 80 & 74.1 & 40 & 93 & 42 & 37.5 & $\mathrm{P} 2=0.021^{*}$ & $\mathrm{P} 2=0.011^{*}$ \\
\hline $\begin{array}{l}\text { - Equivacal positive } \\
\text { (30-40) }\end{array}$ & 6 & 5.5 & 4 & 8.6 & 32 & 29.6 & $\mathrm{P} 3=0.001^{* * *}$ & $\mathrm{P} 3=0.001^{* * *}$ \\
\hline b) Negaive $<30$ & 20 & 18.4 & 2 & 4.4 & 38 & 33.9 & & \\
\hline Total & 108 & 100 & 46 & 100 & 112 & 100 & & \\
\hline
\end{tabular}

- Chi-square test was used

* P1 = group I versus group II

* P2 = group I versus group III | (tested for both total positive and positive

* P3 = group II versus group III $\mid$ cases versus negative cases)

- * = Significant at $\mathrm{P}<0.05 \quad-* *=$ Highly significant at $\mathrm{P}<0.01$

- *** = Extremely significant at $\mathrm{P}<0.001$

- Total positive $=$ positive + equivocal.

Table (3): The level of IgG antibodies of H.pylori (Eu/ml) in sera of the positive cases among the studied group

\begin{tabular}{|l|c|c|}
\hline \multirow{2}{*}{$\begin{array}{l}\text { IgG } \\
\text { Groups }\end{array}$} & \multicolumn{2}{|c|}{ Level of IgG among the positive cases } \\
\cline { 2 - 3 } & Mean + SD & Range \\
\hline Group I No. (80) & $65.3+20.6$ & $41-80$ \\
\hline Group II No. (40) & $85.3+21.6$ & $46-100.3$ \\
\hline Group III No. (42) & $60.5+19.7$ & $40-78.7$ \\
\hline
\end{tabular}

- Test of significance (student $\mathrm{t}$ test)

* Group I versus group II $(\mathrm{P} 1=0.001)=$ extremely significant

* Group I versus group III $(\mathrm{P} 2=0.093)=$ significant

* Group II versus group III $(\mathrm{P} 3=0.001)=$ extremely significant

Table (4): The relation between the skin lesion of rosacea and the level of IgG of H.pylori

\begin{tabular}{|c|c|c|c|}
\hline IgG & $\begin{array}{c}\text { Erythema } \\
(\mathbf{n}=\mathbf{3 0})\end{array}$ & $\begin{array}{c}\text { Papules } \\
(\mathbf{n}=\mathbf{1 0})\end{array}$ & $\begin{array}{c}\text { Pustules } \\
(\mathbf{n}=\mathbf{6})\end{array}$ \\
\hline+ ve & $29(96.6 \%)$ & $7(70 \%)$ & $4(66.7 \%)$ \\
- ve & $1(3.4 \%)$ & $3(30 \%)$ & $2(33.3 \%)$ \\
\hline
\end{tabular}

- Chi-square test was used

- Erythema versus papules $\mathrm{P} 1=0.014 *$ significant

- Erythema versus pustules $\mathrm{P} 2=0.015^{*}$ significant

- Papules versus pustules P3 $=0.88$ non-significant

* Significance at $\mathrm{P}<0.05$

\section{Discussion:}

In this study (Table 1), the selection criteria have included, singleton pregnancy, BMI should be within normal range (mean for the three groups was 25.26) as obesity during the first half of pregnancy is diagnosed if BMI exceeds 29.0 according to ${ }^{[31,32]}$. Also there was no statistically significant difference regarding age, gravidity, gestational age between the different groups. So we excluded risk factors associated with (H.G) like increased body weight ${ }^{[33,34]}$, multiple pregnancy, trophoblastic disease, $[35,34]$. Also, the mean age in the three groups was 25.16 years, as the advanced maternal age is associated with decreased risk for $\left(H . G^{)}{ }^{[33,2]}\right.$.

In table (2), we noticed that, the highest prevalence of H.pylori was among cases of H.G associated with rosacea group II [total positive (positive cases + Equivocal) $=95.6 \%$, followed by H.G without rosacea $79.6 \%$, but in the conrol group, the prevalence was $66.1 \%]$. On the 
other hand, there was extremely significant difference between group II and the control (group III), $\mathrm{P}=0.001$. Also there was significant difference between group II and group I (hyperemesis without rosacea), $\mathrm{P}=$ 0.019 . Regarding the quantitative level of IgG, table (3), showed that the highest titre was among group II, and there was statistically significant differences between this group and group I and III. These results came partially hand in hand with that of 14 who reported that the prevalence of H.pylori infection was $90.5 \%$ in the patients with H.G and $46.5 \%$ in controls. Also from table (2), we noted that the prevalence of H.pylori in group III was $66.1 \%$ which is higher than the reported prevalence in the general population $50 \%-55 \%{ }^{[37,38]}$. We can explain this by the changes in both humoral and cell-mediated immunity occuring during pregnancy. These changes may expose the pregnant women to an increased risk of infection with this microorganism ${ }^{[39,8]}$.

The association of H.pylori with H.G can be explained by the elevated serum steroid hormone and human chorionic gonadotrophin (hCG), which leads to a shift in $\mathrm{pH}$, which hypothetically leads to a change in the gastrointestinal $\mathrm{pH}$. Also these pregnancy-induced hormonal changes are associated with concurrent gastrointestinal dysmotility. Hence the manifestations of subclinical H.pylori infection occurs. These explainations were more or less like that reported by ${ }^{[40,41.4 ; 42,5]}$ As a result of this infection, both systemic and local immune response are elicited in the host. The systemic response occurs as elevated serum specific antibody of IgG, IgA and IgM. Local response occurs as elevated $\operatorname{IgA}$ in gastric juice ${ }^{[43,29]}$. Serum IgG has the higher sensitivity and specifity and is superior to either $\operatorname{IgM}$ and $\operatorname{Ig} \mathrm{A}^{[44,45,46]}$. From these data, $\mathrm{Wu}$ and his 38,28have defined H.pylori infection as a positive serum immunoglobulin $\mathrm{G}$ on doing an immunochromatographic assay.
IgG antibodies serological test was preferred for diagnosis of H.pylori in our study, due to its advantages over the biopsy tests (gastric or skin) in that it is non invasive, simple, sensitive, specific, rapid and of low cost ${ }^{[47,48]}$. So we did not perform histologic studies by gastroscopy or biopsy, considering the high reliability of the IgG assay and because of ethical reasons $[49,50]$.

On the other hand many factors have been considered as a cause of rosacea: infective, alimentary, chemical, thermal, immunologic and endocrinologic, although none of them have been proven to be the actual cause, but mostly rosacea has often been linked with gastrointestinal disturbance [51.20]. This explains the highest prevalence of H.pylori when rosacea is associated with (H.G) as in our study. Also H.pylori can stimulate the synthesis of gastrin (a known flush inducer) and serum gastrin level is usually elevated in H.pylori infected population $^{[\mathbf{1 8 , 1 6}]}$

In the current study, we noted that the erythematous type of rosacea is more prevalent than the other two types (papular and pustular) table (4) . These results were in cordance with that reported by ${ }^{[52,53]}$ who conlcuded that the role of H.pylori is more probable in erythrotic rosacea than in its papulopustular and granulomatous stages. Also ${ }^{[54,55]}$ reported similar results and added that erythema in particular responded better than other types of lesions to eradication of H.pylori. On the other hand by the standards of evidence-based medicine, studies have been often of low quality. The best evidence usually is not indicative of a role for H.pylori in the extradigestive manifestations ${ }^{[56,57]}$

Lastly and not the least, as the transmission of maternal infection with H.pylori to the newborn is high ${ }^{[49,35]}$. So, it might be reasonable to treat hyperemesis gravidarum with a selected therapy which can eradicate H.pylori and at the same time should be safe during the period of 
organogenesis $^{[58]}$. Apart from the therapeutic use of amoxicillin which is cateogry B according to food and drug adminstration classification [59], the administration of effective therapies against H.pylori - like: amoxocillin combined with omprazole, pantoprazole, clarithromycin and metronidazole ,till now are promising and are still a matter of discussion during organogenesis period ${ }^{\left[\mathbf{6 0 0}^{61]}\right.}$. On the other hand some reports have noted marked rapid improvement of severe hyperemesis gravidarum, on oral erythromycin therapy for other non related conditions ${ }^{[62,61]}$. Also the centers for disease control and prevention are recommending the use of metronidazole in all the three trimesters of pregnancy $^{[60,61]}$.

\section{Conclussion and Recommendation}

Chronic infection of H.pylori is suggested to be one of the important factors in the pathogenesis of hyperemesis gravidarum, even though it may not be the single cause of this disorder.

- When rosacea is associated with hyperemesis gravidarum, the obstetrician should expect that H.pylori is often the culprit responisble for the pathogenesis of both.

- More studies are recommended to clarify the different non teratogenic drugs which can be used for eradication of H.pylori during the period of organogenesis. Hence a specific and a causative treatment of hyperemesis gravidarum, well be elicited and at the same time, the transmission of this microorganism from the mother to the fetus is prevented.

\section{References:}

1- Broussard CN and Richter JE: Nausea and vomiting of pregnancy in Gastroenterology clinics of North America Volume 27, Number 1, March, 1998.
2- Hod M, Orvieto R, Kaplan B, et al.: Hyperemesis gravidarum: A review J. Reprod Med 39: 605, 1994.

\section{3- Güngören A, Bayramoğlu N, Duran}

N, Kurul M:. Association of Helicobacter pyloripositivity with the symptoms in patients with hyperemesis gravidarum. Arch Gynecol Obstet. 2013 Dec;288(6):1279-83.

4- Eliakim R, Abulafia O, Sherer DM: Hyperemesis gravidarum: A current review. Am J Perinatal 2000; 17(4): 207-18.

5- Mansour GM, Nashaat EH. Role of Helicobacter pylori in the pathogenesis of hyperemesis gravidarum. Arch Gynecol Obstet. 2011 Oct;284(4):8437.

6- Gross S, Librach C, Cecutti A: Maternal weight loss associated with hyperemesis gravidarum: A predictor of fetal outcome. AM J Obstet Gynecol, 1989; 160: 90615.

7- Tincello DG, Johnstone MJ: Treatment of hyperemesis gravidarum with 5-HT3 antagonist ondansetron (Zofran). Postgrad Med J; 1996; 72: 688.

8- 8-Sandven I, Abdelnoor M, Nesheim BI, Melby KK: Helicobacter pylori infection and hyperemesis gravidarum: a systematic review and meta-analysis of case-control studies. Acta Obstet Gynecol Scand. 2009;88(11):1190-200

9- Howden CW: Clinical expressions of Helicobacter pylori infection. Am J Med, 1996; 100: 275

10-Guven MA, Ertas IE, Coskun A, Ciragil $\mathbf{P}$ :. Serologic and stool antigen assay of Helicobacter pylori infection in hyperemesis gravidarum: which test is 
useful during early pregnancy? Taiwan J

Obstet Gynecol. 2011 Mar;50(1):37-41.

11- Tomb JF, White O, Kerlavage AR et al.: The complete genome sequence of gastric pathogen Helicobacter pylori nature, 1997; 388: 539.

12-Sonkusare S :. Hyperemesis gravidarum: a review. Med J Malaysia. 2008 Aug;63(3):272-6; quiz 277. Review.

\section{3- Bassily S, Frenck RW, Mohareb EW,} Wierzba T, Savarino S, Hall E, Kotkat A, Naficy A, Hyamsk C, Clemens J: Seroprevalence of Helicobacter pylori among Egyptian newborns and their mothers: A preliminary report. Am J Trop Med Hyg 1999 Jul; 61(1): 37-40.

14-Frigo $P$, Lang $C$, Reisenberger $K$, Kolbl H, Hirchl AM: Hyperemesis gravidarum associated with Helicobacter pylori seropositivity. Obstet. Gynecol, 1998; 91: 615-7.

15- Kocak I, Akcan Y, Ustun C, Demirel C, Cengiz L, Yanik FF: Helicobacter pylori seropositivity in patients with hyperemesis gravidarum int. J Gynaecol Obstet 1999 Sep.; 66(3): 251-4.

16-Golberg D, Szilagyi A, Graves L:. Hyperemesis gravidarum and Helicobacter pylori infection: a systematic review. Obstet Gynecol. 2007 Sep;110(3):695-703.

17- Plewig G: Rosacea. In: Fitzpatrick TB, Eisen AZ, Wolff $\mathrm{K}$, Frredberg IM, Austen KF, eds. Dermatology in General Medicine. New York: McGraw-Hill, 1993; P: 727

18-Son SW, Kim IH, OH CH, et al: The response of rosacea to eradication of
Helicobacter pylori (Correspondence). Br J Dermatol, 1999; 140: 964.

19-Utas S, Ozbaki O, Turasan A, Utas C: Helicobacter pylori eradication treatment reduces the severity of rosacea. J Am Acad Dermatol. 1999; 40(3): 433-35.

20-Holmes AD.: Potential role of microorganisms in the pathogenesis of rosacea. J Am Acad Dermatol. 2013 Dec;69(6):1025-32.

21-Powell FC, Dan MA, Duguid C: Positive Helicobacter pylori serology in rosacea patients (Abstratc). Irish J Med Sci, 1992; 161 (Suppl): 75.

22-Robora A, Drago F.: Helicobacter pylori and rosacea. J Am Acad Dermatol, Nov, 2000; 43(5 pt 1): 884.

23-Hirschmann JV: Does helicobacter pylori have a role in the pathogenesis of rosacea. J Am Acad Dermatol, Mar, 2000; 42(3): 537-9

24-Bhattarai S, Agrawal A, Rijal A, Majhi S, Pradhan B, Dhakal SS.: The study of prevalence of Helicobacter pylori in patients with acne rosacea. Kathmandu Univ Med J (KUMJ). 2012 Oct-Dec;10(40):49-52.

25-Herr H, You CH: Relationship between Heliocbacter pylori and rosacea: it may be a myth. J Korean Med Sci Oct, 2000; 15(5): 551-4.

26- Tüzün Y, Keskin S, Kote E.: The role of Helicobacter pylori infection in skin diseases: facts and controversies. Clin Dermatol. 2010 Sep-Oct;28(5):478-82

27-Blecker U, Lanciers S, Vandeplas Y: Evolution of Helicobacter pylori positivity in infants born from positive 
mothers. J Pediatr Gastroenterol, Nutr, 1994; 19: 87-90.

28- Karadeniz RS, Ozdegirmenci O, Altay MM, Solaroglu A, Dilbaz S, Hizel N, Haberal A.: Helicobacter pylori seropositivity and stool antigen in patients with hyperemesis gravidarum. Infect Dis Obstet Gynecol. 2006;2006:73073.

29-Robora A, Drago F, Parodi A: May Helicobacter pylori be important for dermatologists?. Dermatology, 1995; 191(1); 6-8.

30- Cribier B.: Pathophysiology of rosacea: redness, telangiectasia, and rosacea. Ann Dermatol Venereol. 2011 Nov;138 Suppl 3:S184-91.

31-Perez G, Dum M: Diagnosis of Helicobacter pylori infection by serologic methods. In: Compylobatcer pylori AND Gastritis and peptic ulcer diseases. 2010; PP: 163-174, Igaku Shian New York.

32-Zlatnik FJ: Obesity. In: Protocols for high-risk pregnancies. Third edition. Edited by John T. Queenan and John C. Hobbins, 1996; 245.

33-Vandraas K, Vikanes A, Vangen S, Magnus P, Støer N, Grjibovski A:. Hyperemesis gravidarum and birth outcomes-a population-based cohort study of 2.2 million births in the Norwegian Birth Registry. BJOG. 2013 Sep 10.

34-Depue RH, Berstein L, Ross RK, et al.: Hyperemesis gravidarum in relation to estradiol levels, pregnancy outcome, and other maternal factors: A seroepidemiologic study. Am J Obstet Gynecol, 156: 1137, 1987.
35-Ayyavoo A, Derraik JG, Hofman PL, Cutfield WS.: Hyperemesis gravidarum and long-term health of the offspring. Am J Obstet Gynecol. 2013 Nov 23

36-Jarnfelt-Samsioe A， Samsoie G, Velinder G: Nausea and vomiting in pregnancy: A contribution to its epidemiology. Gynecol Obstet Invest 16; 221, 1983.

37-Depue RH, Berstein L, Ross RK, et al.: Hyperemesis gravidarum in relation to estradiol levels, pregnancy outcome, and other maternal factors: A seroepidemiologic study. Am J Obstet Gynecol, 156: 1137, 1987.

38-Wu CY, Tseng JJ, Chou MM, Lin SK, Poon SK, Chen GH: Correlation between Helicobacter pylori infection and gastrointestinal symptoms in pregnancy. Adv Ther 2000; May-Jun; 17(3): 152-8.

39-Vikanes AV, Støer NC, Gunnes N, Grjibovski AM, Samuelsen SO, Magnus P, Melby KK.: Helicobacter pylori infection and severe hyperemesis gravidarum among immigrant women in Norway: a case-control study. Eur J Obstet Gynecol ReprodBiol. 2013 Mar;167(1):41-6.

40-Lanciers S, Despinasse B, Mehta DI, Blecker U: Increased susceptibility to Helicobacter pylori infection in pregnancy. Infect Dis. Obstet Gynecol, 1999; 7(4): 195-8

41-Masson GM, Anthony F, Chau E: Serum choronic gondogrophin (hCG), schwa ngeschafts protein-1 (SP1), progesterone and oestradiol levels in patients with nausea and vomiting in early pregnancy: $\mathrm{Br} \mathrm{J}$ Obstet Gynecol 92; 211, 1985. 
42-La Vecchia C, D'Avanco B, Franceschi S, Negri E, Parazzini F, Decarli A: Menstrual and reproductive factors and gastric cancer risk in women. Int. J Cancer 1994; 69-761-764.

43-Hayakawa S, Nakajima N, KarasakiSuzuki M, Yoshinaga H, Arakawa Y, Satoh K, Yamamoto T: Frequent presence of Helicobacter pylori genome in the salvia of patients with hyperemesis gravidarum. Am J Perinatol 2000; (17(5): 243-7.

44- Rothbone BJ, Wyatt JI, Worley BW, Shires SE, Trejdosiewicz LK, Heatley RVm Losowsky MS: Systemic and local antibody response to gastric campylobacter pylori in non ulcer dyspepsia.Gut, 1986; 27: 624-7.

45- Luzza F, Maletta M, Imeno M, Marcheggiano A, Iannoni C, Biancone L, Pallone F: Salivary specific immunoglobulin $G$ in the diagnosis of Helicobacter pylori infection in dyspeptic patients. Am J Gastrontero, 1995; 90: 1820-3

46- Veenendaal RA, Gotez JM, Schorifen V, Kurban F, Bernards AT, Veselic M, Pena AS, Lamers CBHW: Diagnosis of Helicobacter pylori infection by specific gastric mucosal IgA and IgG pylori antibodies. J Clin Pathol, 1995; 48: 990-3.

47-Aytac S, Türkay C, Kanbay M.: Helicobacter pylori stool antigen assay inhyperemesis gravidarum: a risk factor for hyperemesis gravidarum or not? Dig DisSci. 2007 Oct;52(10):28403.

48-Graham DY, Evans DJ, Pencock J, Baker JT, Schrier WH: Comparison of rapid serological tests (Flex sure HP and quick vue) with conventional ELISA for detection of Helicobacter pylori infection. Am J Gastroenterol, 1996; 91: 442-8.

49-Penney DS.: Helicobacter pylori and severe nausea and vomiting during pregnancy. J Midwifery Womens Health. 2005 Sep-Oct;50(5):418-22.

50-Blecker U, Lanciers S, Hauser B, Metha DI, Vandenplas Y: Serology as a valid screening test for Helicobacter pylori infection in asymptomatic subejcts. Arch Pathol, Lab Med, 1995; 119: 30-2.

51-Greaves MW: Flushing and flushing syndromes, rosacea and perioral dermatitis. In: Rook A, Wilkinson DS, Ebling FJG. Champion RH, Burton JL, Burnsr DA and Breathnach SM, eds. Textbook of Dermatology. London: Blackwell scientific Publications, 1999, P: 2099.

52-Robora A, Drago F, Parodi A: May Helicobacter pylori be important for dermatologists?. Dermatology, 1995; 191(1); 6-8.

53-El-Khalawany M, Mahmoud A, Mosbeh AS, A B D Alsalam F, Ghonaim N, Abou-Bakr A.: Role of Helicobacter pylori in common rosacea subtypes: a genotypic comparative study of Egyptian patients. J Dermatol. 2012 Dec;39(12):989-95.

54- Bamford JT, Tilden RL, Blankush JL, Gangeness DE: Effect of treatment of Helicobacter pylori infection on rosacea. Arch Demratol, 1999 Jun, 135: 6, 65963.

55-Preisz K, Kárpáti S.: Rosacea: pathogenesis, clinical forms and 
therapy]. Orv Hetil. 2010 Jul 25;151(30):1209-14.

56-Dekoster E, DeBruyne I, Langlet $P$, Deltenre M: Evidence based medicine and extradigestive manifestations of Helicobacter pylori. Acta gastroenterol Belg 2000 Oct.-Dec.; 63(4): 388-92.

57-Franceschi F, Roccarina D, Gasbarrini A.: $\quad$ Extragastric manifestations of Helicobacter pylori infection. Minerva Med. 2006 Feb;97(1):39-45.

58-Maltepe C, Koren G:. The management of nausea and vomiting of pregnancy and hyperemesis gravidarum-a 2013 update. J Popul Ther Clin Pharmacol. 2013;20(2)

59- Lewis JH, Weingold AB: The committee on FDA related matters, American College of gastroenterology:
The use of gastrointestinal drugs during pregnancy and lactation. Am. J. Gastroenterol, 1985; 80: 912

60-Frevel M, Daake H, Janisch HD, Kellner HU, Krezdorn HG, Tanneberger D, Wack R: Eradication of Helicobacter pylori with pantoprazole and two antibiotics: a comparison of two short-term regimens. Aliment pharmacol. Ther. Sept,2000, 14(9): 1151-7.

61-Drug Ther Bull. 2013: Management of hyperemesis gravidarum, 2013 Nov;51(11):126-9.

62-El-Younis CM, Abulafia O, Sherer DM: Rapid marked response of severe hyperemesis gravidarum to oral erythromycin. Am J Perinatol, 1998; 15(9): 533-4. 